\title{
Oral health of older people: tracking soft tissue injuries for the prevention of oral cancer
}

\author{
Saúde bucal de idosos: rastreio de lesões dos tecidos moles na prevenção do câncer bucal \\ Salud bucal de personas mayores: rastreo de lesiones de \\ tejidos blandos en la prevención del cáncer bucal
}

Maria Vieira de Lima Saintrain ${ }^{1}$, Anna Beatriz Vieira Bandeira², Luciana Leite Pequeno², Davi Oliveira Bizerril², Paulo Leonardo Ponte Marques², Fernando André Campos Viana²

How to cite this article:

Saintrain MVL, Bandeira ABV, Pequeno LL, Bizerril DO, Marques PLP, Viana FAC. Oral health of older people: tracking soft tissue injuries for the prevention of oral cancer. Rev Esc Enferm USP. 2018;52:e03380. DOI: http://dx.doi.org/10.1590/S1980-220X2017033603380

1 Universidade de Fortaleza,

Programa de Pós-graduação em Saúde Pública, Fortaleza, CE, Brazil.

${ }^{2}$ Universidade de Fortaleza, Departamento de Odontologia, Fortaleza, CE, Brazil.

\begin{abstract}
Objective: To detect oral soft tissue injuries in older people. Method: A quantitative analytical cross-sectional study conducted in Fortaleza, Ceará. Individual interviews addressed age, gender, marital status, income, and education. The community oral health indicator was used to detect oral soft tissue injuries and their location. Results: Most of the 821 participants aged 60-100 years were women $(580 ; 70.6 \%)$, attended school for up to 5 years $(401 ; 48.8 \%)$, were illiterate $(201 ; 24.5 \%)$, were retired $(608 ; 74.1 \%)$, and received up to 2 wages $(701 ; 85.4 \%)$. A total of 604 participants $(73.6 \%)$ wore dentures. Injuries included red patches $(152 ; 55.9 \%)$, blisters $(58 ; 21.3 \%)$, lesions and/ or wounds $(39 ; 14.3 \%)$, and white patches $(30 ; 11 \%)$. Locations of injuries were the roof of the mouth $(167 ; 61.4 \%)$, gums $(62 ; 22.8 \%)$, cheeks $(39 ; 14.3 \%)$, tongue $(15 ; 5.5 \%)$, lips $(15 ; 5.5 \%)$, and the floor of the mouth $(12 ; 4.4 \%)$. Injuries were associated with age $(p<0.001)$, retirement $(p=0.005)$, education $(p=0.010)$, dentures $(p<0.001)$ and red patches $(p<0.001)$. Conclusion: Tracking soft tissue injuries and referring older adults with suspected malignant lesions to the health team should be included as oral cancer identification and prevention measures. Furthermore, health care providers should raise older adults' awareness of the importance of regular preventive examinations.
\end{abstract}

\section{DESCRIPTORS}

Oral Health; Aged; Mouth Neoplasms; Epidemiology. 


\section{INTRODUCTION}

In 2012, the leading causes of noncommunicable diseases (NCDs) deaths were cardiovascular diseases (17.5 million deaths, or $46.2 \%$ of all NCD deaths), cancer (8.2 million, or $21.7 \%$ of all NCD deaths), respiratory diseases - including asthma and chronic obstructive pulmonary disease $-(4.0$ million, or $10.7 \%$ of all NCD deaths) and diabetes (1.5 million, or $4 \%$ of all NCD deaths). These four main noncommunicable diseases were responsible for $82 \%$ of deaths in that period ${ }^{(1)}$ and are part of the epidemiological profile of the aging population, which is characterized by the rise of chronic, degenerative and disabling diseases. Among these diseases are neoplasms, which are a major cause of hospitalization among older users of Primary Care in Brazil's National Health System (Sistema Único de Saúde - SUS) ${ }^{(2)}$.

In this regard, oral cancer has stood out as one of the most prevalent cancer types emerging as a major public health problem worldwide. Oral cancer includes cancers of the lips, tongue and oral cavity. Based on this classification, authors have highlighted more than 5,000 new cases of oral cancer and approximately 1,850 deaths per year in the $\mathrm{UK}^{(3)}$. In the United States of America (USA), a total of $1,658,380$ new cases and 589,430 deaths were expected for the year 2015. In all, 45,780 new cases of cancer of the oral cavity and pharynx were recorded, which included 14,320 cases of tongue cancer, 12,930 cases of mouth cancer, 15,520 cases of pharynx cancer and 3,020 other cases of oral cavity cancer ${ }^{(4)}$. Oral cancer is the most common malignant disorder of the oral cavity, with high incidence rates in several developed countries ${ }^{(5)}$. In Brazil, the National Cancer Institute (Instituto Nacional do Câncer - INCA) registered 600,000 new cases of oncological diseases in 2016 and 2017 and highlighted oral cavity cancer as a major public health problem worldwide and one of the most frequent, with estimates of 11,140 new cases in men and 4,350 in women for 2016, indicating an estimated risk of 11.27 new cases per 100,000 men and 4.21 cases per 100,000 women ${ }^{(6)}$.

The development of cancer is stimulated by a complex interaction of multiple factors that can be either nonmodifiable - genetic mutations, family history, age, gender, race, ethnicity - and modifiable - health behaviors and lifestyle factors (e.g., tobacco and alcohol use, obesity). However, one must consider that environmental risk factors for cancer such as radiation, infectious agents and workplace exposures may be modifiable or nonmodifiable ${ }^{(7)}$. Furthermore, studies have found that potentially precancerous lesions are responsible for $20 \%$ of oral cancer, thus highlighting the importance of a very detailed clinical examination with the visualization of pathological lesions ${ }^{(8-9)}$.

Given the above, the study aimed to detect soft tissues injuries in the mouth in older people attending Primary Health Centers (Unidades Básicas de Saúde - UBS).

\section{METHOD}

This is a quantitative descriptive cross-sectional study conducted with older people living in the city of Fortaleza, located in the State of Ceará, Northeastern Brazil.
The city is divided into six Regional Executive Secretariats (Secretarias Executivas Regionais - SER) and has a total of 93 primary health centers (Unidades Básicas de Saúde - UBS) (10). The city has 2,452,185 inhabitants, 242,430 of whom are older people ${ }^{(10-11)}$. In the present study, anyone who was 60 years old or older was considered to be elderly, in accordance with the World Health Organization ${ }^{(12)}$.

The sample size was calculated based on the number of older inhabitants, using a margin of error of $4 \%$ and a $99 \%$ confidence interval and considering a maximum percentage of $25 \%$ of people with soft tissue injuries, resulting in 776 older people. However, 821 older people were examined, and, therefore, the sampling error decreased.

Older people from all the administrative regions of the city were investigated based on a sample stratified proportionally to the number of people in this age group in each region $^{(10)}$. The research took place in three UBS of each region, which were selected at random.

Data were collected through individual interviews using a questionnaire containing closed-ended questions (dichotomous and multiple choice) addressing sociodemographic data (age, gender, marital status, income, education), soft tissue injury (lesions and/or wound, red patches, white patches, blisters, other lesions) and location of the injury (floor of the mouth, lips, cheek, roof of the mouth, tongue, other places).

Given that epidemiological problems arising from the poor oral health status of older people are still difficult to prevent, it was deemed important to assess the prevalence of oral lesions and obtain data that could provide support for the active screening and prevention of oral cancer using part of the "Community Oral Health Indicator - COHI" (Indicador Comunitário em Saúde Bucal - ICSB) instrument. This instrument was developed and validated for the Brazilian population and is intended to assess masticatory capacity by counting the number of teeth, the need for curative treatment by counting the visible teeth with cavities and residual root, the presence of soft tissue injuries, and the use and need of dental prostheses. Additionally, the COHI features a list of clinical signs related to periodontal and dental cavities problems, as well as soft tissue injuries. The list of seven items (1-no dental cavity; 2-tartar; 3-gingival inflammation; 4-one or two dental cavities; 5-three or more dental cavities; 6-residual root; 7-soft tissue injury) allows the prioritization of individuals with more severe needs, with 1 indicating the lowest priority and 7 the highest priority ${ }^{(13)}$. It is, therefore, a technology strategy to obtain epidemiological data on the population's oral health.

Data were analyzed using the Statistical Package for the Social Sciences-SPSS version 21 (SPSS Inc., Chicago, IL, USA). Statistical measures, such as Pearson's Chi squared test and Prevalence Ratio (PR), allowed researchers to achieve research goals with significance levels set at $5 \%$.

After the research project was approved by the Research Ethics Committee of the University of Fortaleza (Opinion No. 107/2009), three researchers (undergraduate and graduate students) were trained and then informed the participants about the research objectives. The research started after the participants gave their written consent. 


\section{RESULTS}

The ages of the 821 older people examined ranged from $60-100$ years, with a mean age of 69.75 years $(\mathrm{SD} \pm 6.9)$. Most participants were women $(n=580)$, representing $70.6 \%$ of the older patients.

The participants displayed the following characteristics: 603 were retired (73.4\%); 201 could not read and write (24.5\%); 201 had never attended school (24.5\%), while 113 attended school for 10 years or more (13.8\%); and 701 received up to two minimum wages (85.4\%). A total of 604 older patients $(73.6 \%)$ wore dentures.

In all, 272 older patients (33.1\%) presented with soft tissue injuries in the mouth. The types of injuries were classified as follows: red patches $(152 ; 55.9 \%)$; blisters (58; $21.3 \%)$; lesions and/or wounds $(39 ; 14.3 \%)$; white patches (30; 11.0\%); and other injuries $(01 ; 0.03 \%)$ represented by hyperplasic tissue folds. Eight older participants had more than one injury.

The palate was the location of the mouth most affected by injuries $(167 ; 61.4 \%)$, followed by the gums $(62 ; 22.8 \%)$, cheeks $(39 ; 14.3 \%)$, lips $(15 ; 5.5 \%)$, tongue $(15 ; 5.5 \%)$, and floor of the mouth (12; 4.4\%). Statistically significant associations were found between soft tissue injuries and age group $(\mathrm{p}<0.001)$, retirement $(\mathrm{p}=0.005)$, years of education $(\mathrm{p}=0.010)$, use of dentures $(\mathrm{p}<0.001)$, and red patches $(\mathrm{p}<0.001)$.

Patients with suspected malignant lesions were referred to a specialized service.

Table 1 shows the socioeconomic status of the older people examined.

Table 2 shows the relationship between soft tissue injuries and socioeconomic variables, and Table 3 depicts the relationship between soft tissue injuries and use of dentures.
Table 1 - Distribution and relative frequency of older people according to socioeconomic status - Fortaleza, CE, Brazil, 2016.

\begin{tabular}{|c|c|c|}
\hline Variables & Frequency & Percentage \\
\hline \multicolumn{3}{|l|}{ Age Group } \\
\hline 60-69 years old & 441 & 53.7 \\
\hline 70-79 years old & 300 & 36.5 \\
\hline 80 years old and over & 80 & 9.7 \\
\hline \multicolumn{3}{|l|}{ Marital Status } \\
\hline Single & 121 & 14.7 \\
\hline Married & 356 & 43.4 \\
\hline Divorced & 96 & 11.7 \\
\hline Widowed & 248 & 30.2 \\
\hline \multicolumn{3}{|l|}{ Gender } \\
\hline Male & 241 & 29.4 \\
\hline Female & 580 & 70.6 \\
\hline \multicolumn{3}{|l|}{ Retired } \\
\hline Yes & 608 & 74.1 \\
\hline No & 213 & 25.9 \\
\hline \multicolumn{3}{|l|}{ Income } \\
\hline Up to $2 \mathrm{MW}$ & 701 & 85.4 \\
\hline 2-5 MW & 110 & 13.4 \\
\hline More than $5 \mathrm{MW}$ & 10 & 1.2 \\
\hline \multicolumn{3}{|l|}{ Years of Education } \\
\hline None & 201 & 24.5 \\
\hline Up to 5 years & 401 & 48.8 \\
\hline $6-9$ years & 106 & 12.9 \\
\hline 10 years or more & 113 & 13.8 \\
\hline \multicolumn{3}{|l|}{ Use of dentures } \\
\hline Yes & 604 & 73.6 \\
\hline No & 217 & 26.4 \\
\hline
\end{tabular}

MW: Minimum Wages.

Table 2 - Distribution and inferential analysis of soft tissue injuries in relation to socioeconomic variables - Fortaleza, CE, Brazil, 2016.

\begin{tabular}{|c|c|c|c|c|}
\hline Variables & Injuries $\mathrm{n}=272 \mathrm{n}(\%)$ & No injuries $n=549 n(\%)$ & Prevalence Ratio $(95 \% \mathrm{Cl})$ & $p$ value \\
\hline \multicolumn{5}{|l|}{ Age Group } \\
\hline $70-79$ years old & $126(42.0)$ & $174(58.0)$ & $1.5(1.3-1.9)$ & $<0.001 *$ \\
\hline 80 years old and over & $25(31.3)$ & $55(68.8)$ & $1.1(0.8-1.6)$ & \\
\hline 60-69 years old & $121(27.4)$ & $320(72.6)$ & 1 & \\
\hline \multicolumn{5}{|l|}{ Marital Status } \\
\hline Married & $116(32.6)$ & $240(67.4)$ & $1.2(0.8-1.6)$ & $0.415^{*}$ \\
\hline Divorced & $37(38.5)$ & $59(61.5)$ & $1.4(0.9-2.0)$ & \\
\hline Widowed & $85(34.3)$ & $163(65.7)$ & $1.2(0.9-1.7)$ & \\
\hline Single & $34(28.1)$ & $87(71.9)$ & 1 & \\
\hline \multicolumn{5}{|l|}{ Gender } \\
\hline Female & $203(35.0)$ & $377(65.0)$ & $1.2(1.0-1.5)$ & $0.077^{*}$ \\
\hline Male & $69(28.6)$ & $172(71.4)$ & 1 & \\
\hline \multicolumn{5}{|l|}{ Retired } \\
\hline Yes & $218(35.9)$ & $390(64.1)$ & $1.4(1.1-1.8)$ & $0.005^{*}$ \\
\hline No & $54(25.4)$ & $159(74.6)$ & 1 & \\
\hline \multicolumn{5}{|l|}{ Income } \\
\hline Up to $2 \mathrm{MW}$ & $242(34.5)$ & $459(65.5)$ & $1.7(0.5-6.0)$ & $0.118^{* *}$ \\
\hline $2-5 \mathrm{MW}$ & $28(25.5)$ & $82(74.5)$ & $1.3(0.4-4.6)$ & \\
\hline More than $5 \mathrm{MW}$ & $2(20.0)$ & $8(80.0)$ & 1 & \\
\hline \multicolumn{5}{|l|}{ Years of education } \\
\hline None & $66(32.8)$ & $135(67.2)$ & $1.0(0.7-1.6)$ & $0.010^{*}$ \\
\hline Up to 5 years & $149(37.2)$ & $252(62.8)$ & $1.8(1.2-2.7)$ & \\
\hline $6-9$ years & $34(32.1)$ & $72(67.9)$ & $1.6(1.0-2.5)$ & \\
\hline 10 years or more & $23(20.4)$ & $90(79.6)$ & 1 & \\
\hline
\end{tabular}

*Analysis using chi-squared test. ${ }^{* *}$ Analysis using fisher's exact test. 
Table 3 - Distribution and inferential analysis of soft tissue injuries in relation to the use of dentures - Fortaleza, CE, Brazil, 2016.

\begin{tabular}{|c|c|c|c|c|}
\hline \multirow[t]{2}{*}{ Variables } & $\begin{array}{l}\text { Denture } \\
n=604\end{array}$ & $\begin{array}{l}\text { No denture } \\
\mathrm{n}=217\end{array}$ & \multirow{2}{*}{$\begin{array}{l}\text { Prevalence Ratio } \\
\quad(95 \% \mathrm{Cl})\end{array}$} & \multirow[t]{2}{*}{$p$ value } \\
\hline & n (\%) & n (\%) & & \\
\hline \multicolumn{5}{|c|}{ Soft tissue injuries } \\
\hline Yes & $225(82.7)$ & $47(17.3)$ & $1.2(1.1-1.3)$ & $<0.001$ \\
\hline No & $379(69.0)$ & $170(31.0)$ & 1 & \\
\hline \multicolumn{5}{|l|}{ Blisters } \\
\hline Yes & $43(74.1)$ & $15(25.9)$ & $1.0(0.9-1.2)$ & 0.919 \\
\hline No & $561(73.5)$ & $202(26.5)$ & 1 & \\
\hline \multicolumn{5}{|c|}{ Lesions and/or wounds } \\
\hline Yes & $30(76.9)$ & $9(23.1)$ & $1.0(0.9-1.3)$ & 0.626 \\
\hline No & $574(73.4)$ & $208(26.6)$ & 1 & \\
\hline \multicolumn{5}{|c|}{ Red patches } \\
\hline Yes & $135(88.8)$ & $17(11.2)$ & $1.3(1.2-1.4)$ & $<0.001$ \\
\hline No & $469(70.1)$ & $200(29.9)$ & 1 & \\
\hline \multicolumn{5}{|c|}{ White patches } \\
\hline Yes & $24(80.0)$ & $6(20.0)$ & $1.1(0.9-1.3)$ & 0.416 \\
\hline No & $580(73.3)$ & $211(26.7)$ & 1 & \\
\hline
\end{tabular}

Chi-Squared Test.

\section{DISCUSSION}

The older population in the present research was predominantly female with low education and income.

The low education level of the Brazilian population 60 years old and over is displayed by the social indicators of the Brazilian Institute of Geography and Statistics (Instituto Brasileiro de Geografia e Estatística), which reveals an average of 4.2 years of education, $28.1 \%$ of the population having less than one (1) year of education, and only $7.2 \%$ having an undergraduate degree. In addition, the majority of older Brazilians (76.3\%) receive social security benefits, which is consistent with the findings of the present research ${ }^{(14)}$.

The large number of oral soft tissue injuries found (33.1\%) represents an opportunity to increase the proportion of oral cancer detected at the earliest stage. This could be achieved by referring patients with soft tissue injuries that need biopsy to specialized oral health care centers ${ }^{(15)}$.

Some injuries are called premalignant or precancerous as they may precede a type of oral malignancy. However, it is important to note that not all these injuries necessarily progress to a mouth cancer, and not all oral cancers are preceded by these pathologies. These injuries include leukoplakia, erythroplakia, actinic cheilitis, and lichen planus and are manifested in the oral cavity in the form of white and red patches, ulcers, blisters, plaque, and papules, among others $^{(9,16)}$.

Knowing the epidemiology of soft tissue injuries is essential to prevent or minimize damage from malignant lesions, especially when there are insufficient records between the period of detection and confirmation of the diagnosis of oral cancer. In addition, health care services need to carry out a better monitoring of patients with soft tissue injuries ${ }^{(17)}$, particularly older adults, as aging is the major risk factor for developing cancer ${ }^{(18)}$.

In the present study, red patches, bullous lesions, wounds and ulcers were detected, which corroborates the findings of another study ${ }^{(16)}$. Considering the analyses of these authors, the large number of red patches found in the present study, which accounted for $55.9 \%$ of injuries, is worrisome. At the same time, this type of injury can indicate various oral pathologies, such as erythroplakia, which is a rare but complex condition that is the main premalignant disease given its high degree of epithelial atypia ${ }^{(8)}$.

Additionally, the bullous lesions found in $7.1 \%$ of the sample can be representative of various oral problems, such as a simple mucocele or a complex lichen planus. Regarding wounds and ulcers ( $4.8 \%$ of the sample), they can also suggest various oral diseases, including canker sores, trauma or more complex processes such as actinic cheilitis ${ }^{(8,16)}$.

As for the white patches, they were less frequent in the present study (3.7\%); however, they are not less important. Despite the small percentage of cases of white patches, these lesions are very severe as they may be indicative of leukoplakia, the most common precancerous injury ${ }^{(16)}$.

White patches have been found to be more commonly associated with smoking ${ }^{(19)}$. Considering the occurrence of harmful habits, the risk of oral cancer is increased when the use of tobacco and alcohol are combined ${ }^{(5)}$.

There are other forms of oral soft tissue injuries - for instance, the hyperplastic tissue folds found in the present study. These folds are formed in response to the use of ill-fitting dentures and are characterized by the condition known as epulis fissuratum or inflammatory fibrous hyperplasia. Additionally, denture stomatitis is an inflammatory and/or hyperplastic reaction of the denture covered mucosa 
in response to the mechanical irritation produced by the denture and/or infections ${ }^{(20)}$.

Data from a meta-analysis have shown that the use of dentures is associated with an increased risk of developing cancer (OR: 1.42, 95\% CI: 1.01-1.99) and that ill-fitting dentures substantially increase the risk of developing cancer (OR: 3.90, 95\% CI: 2.48-6.13) ${ }^{(21)}$.

The palate was the location with the highest incidence of injuries, with a strong relationship to the use of dentures. A study conducted with 889 older people reported that most of the lesions found were the result of denture misuse ${ }^{(22)}$. This relationship is also supported by research carried out at the Universidade of Fortaleza (UNIFOR), located in the state of Ceará, Northeastern Brazil, in which researchers reported that most oral injuries in older people are associated with the use of dentures, particularly with regard to their production and hygiene ${ }^{(23)}$. Other studies also demonstrate this relationship. For example, a review of medical records found a total of $39.5 \%$ of patients with soft tissue injuries, $78.0 \%$ of whom were diagnosed with denture stomatitis ${ }^{(24)}$. The same was found in another study in which injuries appeared in 69\% of patients, and denture stomatitis was observed in $44.6 \%$ of the cases ${ }^{(25)}$.

Research has detected oral injuries in $20.5 \%$ of cases in denture wearers ${ }^{(26)}$. Denture-induced fibrous hyperplasia was the most common type of injury detected (41.9\%), with a significant correlation $(p=0.004)$ between the type of denture and oral injuries. According to the authors, these injuries depend on the material and quality of the dentures, the techniques used and the methods of instruction offered and adopted by patients.

Therefore, the professional responsible for producing the dentures should pay due attention to retention and stability aspects and provide patients with appropriate information about hygiene and storage.

It is at this juncture that oral cancer has been recognized as a public health problem. It is a major problem not only because of its impact but also because of the context of the disease, which includes risk factors, the impact of the diagnosis, confirmation, and treatment. All these factors have a significant impact on the lifestyle of the individual and the family and on the adherence to treatment, which is usually aggressive given its adverse effects ${ }^{(18)}$.
Within this context and based on the results of the present study, primary care dentists and surgeons should refer patients to cancer treatment facilities for early diagnosis and treatment, as routine biopsy in those clinically presenting with features of precancerous lesions may lead to early diagnosis of oral cancer ${ }^{(27)}$.

It should be noted that patients treated for oral cancer experienced significantly worse physical domains of HRQoL (Health-Related Quality of Life) and OHRQoL (Oral Health-Related Quality of Life) compared to the general population, even after adjusting for the effect of sociodemographic characteristics, oral health, and general health. These differences were moderate for the physical domains of HRQoL and severe for OHRQoL. On the other hand, the results suggest that there could be a psychological adaptation over time in these patients ${ }^{(28)}$.

Therefore, early detection of oral injuries through simple and permanent screening should be a premise for oral health and systemic health care. Likewise, it should be based on health promotion, prevention of dental caries and periodontal diseases as well as health education to prevent harmful habits.

The fact that the present research focused on a single city represents a limitation of the study, as it prevents the extrapolation of results. However, because it is a large city, it is expected that the findings are true in other locations and serve to measure the impact of oral soft tissue injuries on the prevention of precancerous conditions.

In addition, they can serve as a basis for targeting public policies since oral health as an essential factor for general human health and quality of life for older people. Further studies should improve research in this area.

\section{CONCLUSION}

It can be inferred from the results of the present study that there is a close relationship between most oral injuries and the use of ill-fitting dentures. The use of dentures, particularly ill-fitting dentures, or even their poor hygiene, can lead to complications that may progress to oral cancer. Therefore, tracking soft tissue injuries and referring patients with suspected malignant lesions should be included as oral cancer identification and prevention measures.

\section{RESUMO}

Objetivo: Detectar agravos aos tecidos moles orais em pessoas idosas. Método: Estudo quantitativo, analítico, transversal, realizado. As entrevistas individuais abordaram idade, sexo, estado civil, renda e educação. O Indicador Comunitário de Saúde Bucal foi utilizado para detectar agravos aos tecidos moles orais e sua localização. Resultados: A maioria dos 821 participantes tinha entre 60 e 100 anos, era mulheres $(580 ; 70,6 \%)$, com até 5 anos de escolaridade $(401 ; 48,8 \%)$, analfabeta $(201 ; 24,5 \%)$, aposentada $(608 ; 74,1 \%)$, recebia até dois salários $(701 ; 85,4 \%)$ e $604(73,6 \%)$ usava prótese dentária. Os agravos incluíram manchas vermelhas $(152 ; 55,9 \%)$, bolhas $(58$; $21,3 \%)$, lesões e/ou feridas $(39 ; 14,3 \%)$ e manchas brancas $(30 ; 11 \%)$. As localizações foram palato $(167 ; 61,4 \%)$, gengivas $(62 ; 22,8 \%)$, bochechas $(39 ; 14,3 \%)$, língua $(15 ; 5,5 \%)$; lábios $(15 ; 5,5 \%)$ e assoalho da boca $(12 ; 4,4 \%)$. As localizações estiveram associadas à idade (p $<0,001)$, aposentadoria $(\mathrm{p}=0,005)$, escolaridade $(\mathrm{p}=0,010)$, próteses $(\mathrm{p}<0,001)$ e manchas vermelhas $(\mathrm{p}<0,001)$. Conclusão: Rastrear agravos aos tecidos moles e encaminhar idosos com suspeita de lesões malignas à equipe de saúde devem ser medidas de identificação e prevenção do câncer bucal. Além disso, os profissionais de saúde devem conscientizar os idosos da importância de exames preventivos regulares.

\section{DESCRITORES}

Epidemiologia; Saúde bucal; Idoso; Neoplasias bucais. 


\section{RESUMEN}

Objetivo: Detectar agravamientos en los tejidos blandos orales en personas mayores. Método: Estudio cuantitativo, analítico, trasversal, llevado a cabo en Fortaleza, Ceará. Entrevistas individuales abordaron edad, sexo, estado civil, ingresos y educación. El Indicador Comunitario de Salud Bucal fue utilizado para detectar agravamientos a los tejidos blandos orales y su ubicación. Resultados: La mayoría de los 821 participantes tenían entre 60 y 100 años, estaba compuesto de mujeres (580; 70,6\%), con hasta 5 años de escolaridad (401; 48,8\%), analfabetas $(201 ; 24,5 \%)$, jubiladas $(608 ; 74,1 \%)$, cobraban hasta dos sueldos mínimos $(701 ; 85,4 \%)$ y $604(73,6 \%)$ llevaban prótesis dental. Los agravamientos incluyeron manchas rojas (152; 55,9\%), burbujas (58; 21,3\%), lesiones y/o heridas (39; 14,3\%) y manchas blancas (30; 11\%). Las ubicaciones fueron paladar (167; 61,4\%), encías (62; 22,8\%), mejillas (39; 14,3\%), lengua (15; $5,5 \%)$, labios $(15 ; 5,5 \%)$ y suelo de la boca $(12 ; 4,4 \%)$. Las ubicaciones estuvieron asociadas con la edad ( $<<0,001)$, jubilación ( $p=0,005)$, escolaridad $(\mathrm{p}=0,010)$, prótesis $(\mathrm{p}<0,001)$ y manchas rojas $(\mathrm{p}<0,001)$. Conclusión: Rastrear agravamientos a los tejidos blandos y derivar a las personas mayores con sospecha de lesiones malignas al equipo de salud deben ser medidas de identificación y prevención del cáncer bucal. Además, los profesionales sanitarios deben concienciar a los ancianos acerca de la importancia de hacer exámenes preventivos regulares.

\section{DESCRIPTORES}

Salud Bucal; Anciano; Neoplasias de la Boca; Epidemiología.

\section{REFERENCES}

1. World Health Organization. Global status report on noncommunicable diseases [Internet]. Geneva: WHO 2014 [cited 2017 Aug 11]. Available from: http://www.who.int/nmh/publications/ncd-status-report-2014/en/

2. Pagotto V, Silveira EA, Velasco WD. Perfil das hospitalizações e fatores associados em idosos usuários do SUS. Ciênc Saúde Coletiva [Internet]. 2013 [citado 2017 ago. 11];18(10):3061-70. Disponível em: http://www.scielo.br/pdf/csc/v18n10/v18n10a31.pdf

3. Speight $\mathrm{P}$, Warnakulasuriya $\mathrm{S}$, Ogden $\mathrm{G}$, editors. Early detection and prevention of oral cancer: a management strategy for dental practice. London: British Dental Association; 2010.

4. Siegel RL, Miller DM, Jemal A. Cancer statistics. CA Cancer J Clin. 2015;65(1):5-29.

5. Del Corso G, Villa A, Tarsitano A, Gohel A. Current trends in oral cancer: a review. Can Cell Microenviron. 2016;3:e1332.

6. Instituto Nacional do Câncer José de Alencar Gomes da Silva. Estimativa 2016: incidência de câncer no Brasil [Internet]. Rio de Janeiro: INCA; 2016 [citado 2017 ago. 10]. Disponível em: http://www.inca.gov.br/bvscontrolecancer/publicacoes/edicao/Estimativa_2016.pdf

7. Ohio Department of Health. Non-modifiable, modifiable and environmental risk factors for cancer. Columbus: ODH; 2015.

8. Hadzic S, Gojkov-Vukelic M, Pasic E, Dervisevic A. Importance of early detection of potentially malignant lesions in the prevention of oral cancer. Mater Sociomed. 2017;29(2):129-33.

9. Paré A, Joly A. Cancers de la cavité buccale: facteurs de risque et prise en charge. Presse Méd. 2017;46(3):320-30.

10. Saintrain MVL, Freitas SKS, Dias AA, Freitas LP, Pequeno LL. Comparison of ohip-14 and gohai measures in relation to sociodemographic factors in older people. Int J Res Stud Bioci. 2016;4(8):22-30.

11. Brasil. Ministério da Saúde. DATASUS. População residente no Estado do Ceará [Internet]. 2012 [citado 2017 ago. 12]. Disponível em: http://tabnet.datasus.gov.br/cgi/tabcgi.exe?ibge/cnv/popce.def.

12. World Health Organization. Active ageing: a policy framework [Internet]. Geneva: WHO; 2002 [cited 2017 Aug 11]. Available from: http:// www.who.int/ageing/publications/active_ageing/en/

13. Saintrain MVL, Vieira APGF. Application of the community oral health indicator by non-dental personnel and its contribution to oral healthcare. PLoS One [Internet]. 2012 July [cited 2017 Aug 11];7(7):e39733. Available from: http://journals.plos.org/plosone/ article?id=10.1371/journal.pone.0039733

14. Instituto Brasileiro de Geografia e Estatística. Síntese de indicadores sociais: uma análise das condições de vida da população brasileira [Internet]. Rio de Janeiro: IBGE; 2013 [citado 2017 ago. 10]. Disponível em: http://biblioteca.ibge.gov.br/visualizacao/livros/liv66777.pdf

15. Noro LRA, Landim JR, Martins MCA, Lima YCP. The challenge of the approach to oral cancer in primary health care. Ciênc Saúde Coletiva [Internet]. 2017 [cited 2018 Apr 12];22(5):1579-1587. Available from: http://www.scielo.br/pdf/csc/v22n5/1413-8123-csc-22-05-1579.pdf

16. Martins RB, Giovani EM, Villalba H. Lesões cancerizáveis na cavidade bucal. Rev Inst Ciênc Saúde [Internet]. 2008 [citado 2017 ago. 14];26(4):467-76. Disponível em: http://files.bvs.br/upload/S/0104-1894/2008/v26n4/a1748.pdf.

17. Sampaio ETM, Oliveira AMG, Pereira AC, Meneghim MC. Acesso ao tratamento do câncer bucal na região do colegiado de gestão regional de Campinas - SP: estudo de caso. Rev Odontol Univ Cid São Paulo. 2015;27(2):150-55.

18. Niccoli T, Partridge L. Ageing as a risk factor for disease. Curr Biol. 2012;22(17):R741-52.

19. Napier SS, Speight PM. Natural history of potentially malignant oral lesions and conditions: an overview of the literature. J Oral Pathol Med. 2008;37(1):1-10.

20. Melo NMC, Sampaio MCC, Soares MSM. Estomatites protéticas: aspectos clínicos e micológicos. Sanitas. 2001;7(13):35-45.

21. Manoharan S, Nagaraja V, Eslick GD. Ill-fitting dentures and oral cancer: a meta-analysis. Oral Oncol. 2014;50(11):1058-61.

22. Espinoza I, Rojas R, Aranda W, Gamonal J. Prevalence of oral mucosal lesions in elderly people in Santiago, Chile. J Oral Pathol Med. 2003;32(10):571-5.

23. Saintrain MVL, Almeida CB, Naruse TMO, Gonçalves VP. Oral lesions in elderly patients of a community in Brazilian Northeast. Gerodontology. 2013;30(4):283-7. 
24. Maciel SSSV, Souza RSV, Donato LMA, Albuquerque IGM, Donato LFA. Prevalência das lesões de tecidos moles causadas por próteses removíveis. Pesq Bras Odontopediatria Clín Integr. 2008;8(1):93-97.

25. Bomfim IPR, Soares DG, Tavares GR, Santos RC, Araújo TP, Padilha WWN. Prevalência de lesões de mucosa bucal em pacientes portadores de prótese dentária. Pesq Bras Odontopediatr Clín Integr. 2008;8(1):117-21.

26. Mubarak S, Ali Hmud A, Chandrasekharan S, Ali AA. Prevalence of denture-related oral lesions among patients attending College of Dentistry, University of Dammam: a clinico-pathological study. J Int Soc Prev Community Dent. 2015;5(6):506-12.

27. Sankaranarayanan R, Ramadas K, Amarasinghe H, Subramanian S, Johnson N. Oral cancer: prevention, early detection, and treatment. In: Gelband H, Jha P, Sankaranarayanan R, Horton S, editors. Cancer: disease control priorities, Washington: World Bank; 2015.

28. Barrios R, Bravo M, Gil-Montoya JA, Martínez-Lara I, García-Medina B, Tsakos G. Oral and general health-related quality of life in patients treated for oral cancer compared to control group. Health Qual Life Outcomes. 2015;13:9. 